\title{
Identification of ESUs in the critically endangered Portuguese minnow Chondrostoma lusitanicum Collares-Pereira 1980, based on a phylogeographical analysis
}

\author{
J. I. Robalo $\cdot$ I. Doadrio $\cdot$ A. Valente * \\ V. C. Almada
}

Received: 3 November 2006/ Accepted: 6 December 2006

(C) Springer Science+Business Media B.V. 2007

\begin{abstract}
In this paper, we analysed the phylogeography of the Critically Endangered fish Chondrostoma lusitanicum (Cyprinidae) endemic to Portugal. A fragment of the mitochondrial cyt $b$ gene and one from the nuclear beta-actin gene were sequenced. The results support recognition of 3 ESU's distributed as follows: 1) Sado River, 2) the Tagus River basin and 3 independent nearby coastal rivers (collectively named "West") and 3) Lagoa de Albufeira, a small coastal lagoon between Tagus and Sado basins.
\end{abstract}

Keywords Phylogeography · Portugal · Critically endangered species · Endemic fish

\section{Introduction}

Chondrostoma lusitanicum is a small cyprinid endemic to Portugal and considered Critically Endangered

J. I. Robalo $(\bowtie) \cdot$ A. Valente · V. C. Almada

Unidade de Investigação em Eco-Etologia, Instituto

Superior de Psicologia Aplicada, Rua Jardim do Tabaco 44,

Lisboa 1149-041, Portugal

e-mail: jrobalo@ispa.pt

A. Valente

e-mail: acvalent@fc.up.pt

I. Doadrio

Museo Nacional de Ciencias Naturales, José Gutiérrez

Abascal 2, Madrid 28006, Spain

e-mail: mcnd147@mncn.csic.es

J. I. Robalo · A. Valente

Departamento de Zoologia e Antropologia, Faculdade de Ciências, Universidade do Porto, Praça Gomes Teixeira,

Porto 4099-002, Portugal
(Cabral et al. 2005), whose range is restricted to the basins of lower Tagus (e.g. Rivers Trancão, Maior, Jamor, Lage and Ossos, see Fig. 1), Sado, and a number of small independent drainages that are in the neighbourhood of those rivers. It also occurs in Lagoa de Albufeira, a very small coastal lagoon between Tagus and Sado (Fig. 1). Its habitat is composed mostly by small Mediterranean type streams which are prone to very severe droughts, while the proximity of most streams to big cities like Lisbon and Setúbal means that these waters are subjected to very strong pollution caused by urban, industrial and agricultural sources. In this context, it is urgent to delineate a conservation strategy for the species and the prospect of ex-situ reproduction for populations that live in streams where the habitat became unsuitable must be considered.

To achieve this goal a proper identification of the units to be conserved is an essential prerequisite. The first attempt to address this issue with DNA data was made by Mesquita et al. (2001). However, only mitochondrial data were included, sample size was very limited (only 22 individuals of $C$. lusitanicum were analysed) and geographical coverage was very incomplete (e.g. only two fish were analysed in the entire Tagus basin and only one of the independent small drainages where the species occurs was included).

In this paper we present data on the phylogeography of the species, covering most of its range, in order to identify the ESUs (Evolutionary Significant Units, sensu Waples 1991) that make up the species. According to Waples (1991) an ESU can be defined as a population or population group with historical isolation and adaptive distinction from other populations within the species, and therefore representing a significant portion of the evolutionary legacy of the species. 
Fig. 1 Map of the Iberian Peninsula with the distribution of C. almacai (darker area) and $C$. lusitanicum (lighter shading) and detail of the main drainages sampled. Labels of collecting sites in the map: (1) Maior, (2) Lizandro, (3)

Samarra, (4) Colares, (5) Lage, (6) Ossos, (7) Jamor, (8) Lagoa de Albufeira

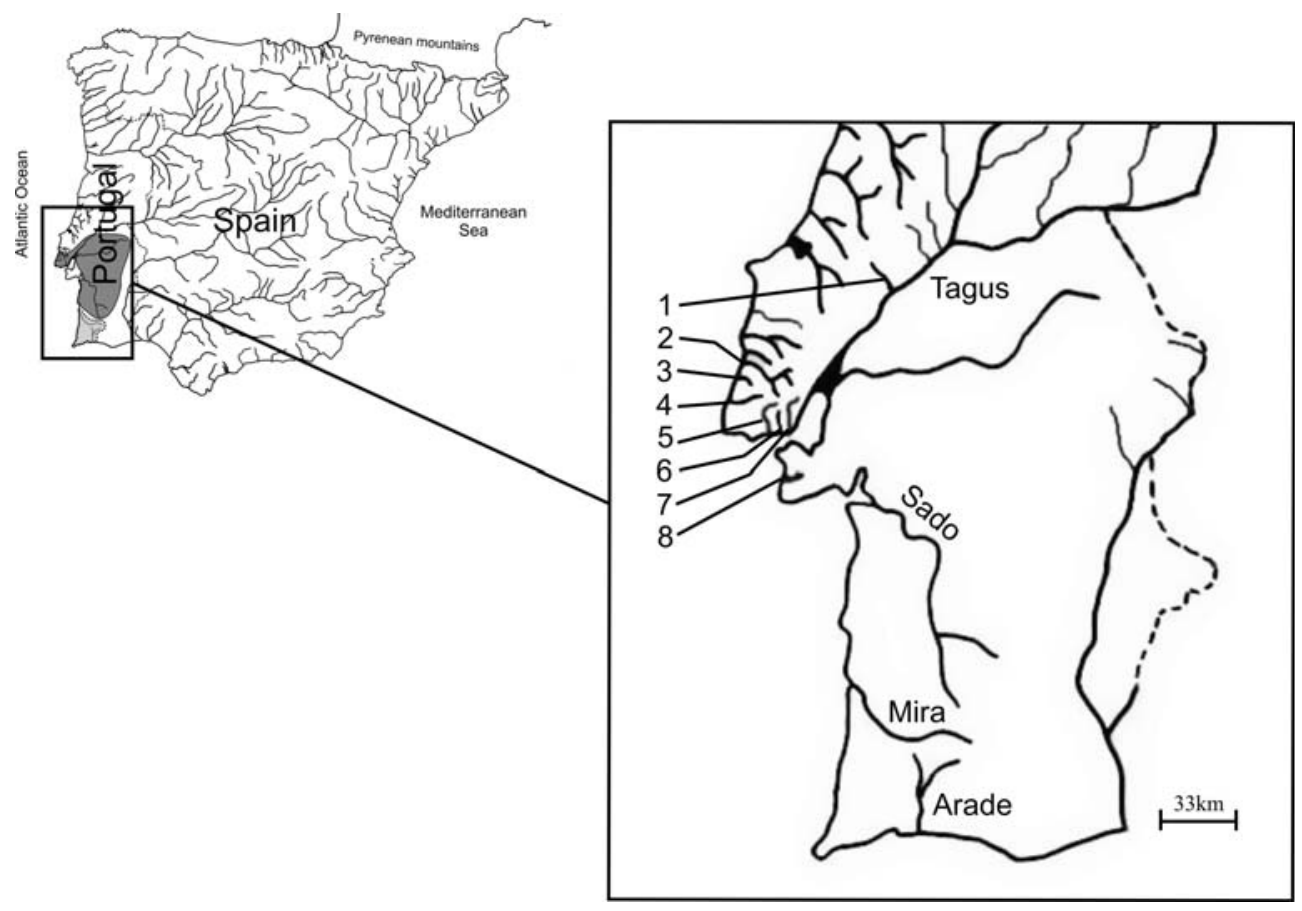

\section{Methods}

Individuals of $C$. lusitanicum were sampled from ten sites (Fig. 1, Table 1). Sixty-five individuals were sequenced for the cyt $b$ and 42 for the beta-actin gene (Table 1).

Total genomic DNA was extracted from ethanol preserved fin clips by an SDS/proteinase-k-based protocol (adapted from Sambrook et al. 1989). 726 bp and $871 \mathrm{bp}$ were amplified for the cyt $b$ and beta-actin genes respectively. Primers and PCR conditions used are those reported in Robalo et al. (2006). Sequencing reactions were performed by Macrogen Inc.

All sequences were deposited in GenBank. Sequences were aligned with Clustal X (Thompson et al. 1997) and analysed using distance (neighbour-joining, $\mathrm{NJ}$ ) and maximum parsimony (MP) using PAUP 4.0 (Swofford 1998). The uncorrected $p$ distance was used. Chondrostoma almacai Coelho, Mesquita, CollaresPereira 2005 was used as outgroup.

ARLEQUIN version 3.01 (Schneider et al. 2000) was used to estimate genetic diversity, mean number of pairwise differences for each pair of populations and to perform analysis of molecular variance (AMOVA; Excoffier et al. 1992). Mean numbers of pairwise differences were corrected by subtracting the average within population differences for the populations of each pair, as implemented in ARLEQUIN. Subsequently these values were transformed in percent sequence divergence after dividing the number of pairwise differences by the length of the DNA fragment analysed.

\section{Results}

For the cyt $b$ gene, among all the sequences studied, 65 sites were variable and 55 were parsimony informative. Twenty-two haplotypes were found in the samples studied. MP analysis resulted in a consensus tree of 75 steps (Consistency index $=0.88$; Homoplasy Index $=0.12 ;$ Retention Index $=0.96 ; \quad$ CI excluding uninformative characters $=0.86$; HI excluding uninformative characters $=0.14$ : Rescaled consistency in$\operatorname{dex}=0.85$ ) (Fig. 2).

The phylogenetic trees derived from the cyt $b$ gene and using the two inference methods converged in the same basic topology. They support the monophyly of C. lusitanicum. The phylogenetic tree consistently differentiates two groups, one including fish from the Sado basin and another including fish from Lagoa de Albufeira and all populations that we grouped as "West". For cyt $b$, the mean divergence between Sado and "West" and between Sado and Lagoa de Albufeira, after correcting for within population variation, is $2.01 \%$ and $1.9 \%$ respectively.

AMOVA performed considering a single group with three populations: "West", Lagoa de Albufeira and Sado, showed that among population variation explained $87,19 \%$ of the variance and was highly significant $(P<0.001)$. All comparisons involving pairs of populations were significant at the same p level (FST values, "West"-Lagoa de Albufeira $=0.41$; "West"Sado $=0.92$; Lagoa de Albufeira-Sado $=0.89$ ). Concerning the genetic diversity, most indices support the 
Table 1 Collecting sites, number of individuals and number of haplotypes for cyt $b$ and beta-actin genes. Number of polymorphic sites, gene diversity, nucleotide diversity and mean number of pairwise differences per group of populations studied, for cyt $b$ gene

\begin{tabular}{|c|c|c|c|c|c|c|c|c|c|c|}
\hline & \multicolumn{7}{|c|}{ Cyt $b$} & \multicolumn{3}{|c|}{ Beta-actin } \\
\hline & $n^{1}$ & $n^{2}$ & $\begin{array}{l}\text { Number } \\
\text { of } \\
\text { haplotypes }\end{array}$ & $\begin{array}{l}\text { Number of } \\
\text { polymorphic } \\
\text { sites }\end{array}$ & $\begin{array}{l}\text { Gene } \\
\text { diversity }\end{array}$ & $\begin{array}{l}\text { Nucleotide } \\
\text { diversity }\end{array}$ & $\begin{array}{l}\text { Mean number } \\
\text { of pairwise } \\
\text { differences }\end{array}$ & $n^{1}$ & $n^{2}$ & $\begin{array}{l}\text { Number } \\
\text { of haplotypes }\end{array}$ \\
\hline \multicolumn{11}{|l|}{ C. lusitanicum } \\
\hline "West" & & 39 & 7 & 8 & $\begin{array}{l}0.3279 \\
\quad \pm 0.0962\end{array}$ & $\begin{array}{l}0.0016 \\
\quad \pm 0.0012\end{array}$ & $\begin{array}{l}1.1309 \\
\quad \pm 0.7512\end{array}$ & & 33 & 1 \\
\hline Trancão * & 3 & & & & & & & 2 & & "West" and Lagoa \\
\hline Maior * & 5 & & & & & & & 5 & & de Albufeira \\
\hline Jamor $*$ & 4 & & & & & & & 3 & & share the same \\
\hline Lage* & 5 & & & & & & & 4 & & haplotype \\
\hline Ossos* & 3 & & & & & & & 2 & & \\
\hline Colares & 7 & & & & & & & 4 & & \\
\hline Samarra & 9 & & & & & & & 3 & & \\
\hline Lizandro & 4 & & & & & & & 3 & & \\
\hline $\begin{array}{l}\text { Lagoa de } \\
\text { Albufeira }\end{array}$ & 12 & 12 & 4 & 6 & $\begin{array}{l}0.6364 \\
\quad \pm 0.1277\end{array}$ & $\begin{array}{l}0.0027 \\
\quad \pm 0.0019\end{array}$ & $\begin{array}{l}1.9697 \\
\pm 1.1964\end{array}$ & 7 & 7 & 1 \\
\hline Sado & 14 & 14 & 7 & 7 & $\begin{array}{l}0.8242 \\
\quad \pm 0.0781\end{array}$ & $\begin{array}{l}0.0019 \\
\quad \pm 0.0014\end{array}$ & $\begin{array}{l}1.3956 \\
\pm 0.9099\end{array}$ & 9 & 9 & 1 \\
\hline C. almacai & & 23 & 4 & 3 & $\begin{array}{l}0.4862 \\
\quad \pm 0.1053\end{array}$ & $\begin{array}{l}0.0008 \\
\quad \pm 0.0007\end{array}$ & $\begin{array}{l}0.5771 \\
\quad \pm 0.4837\end{array}$ & & 7 & 1 \\
\hline Mira & 18 & & & & & & & 5 & & \\
\hline Arade & 5 & & & & & & & 2 & & \\
\hline
\end{tabular}

$n^{1}$-number of samples per drainage; $n^{2}$-number of samples per group of populations considered in this study. Names marked with * represent tributaries of the lower Tagus. For location of sample sites see Fig. 1. GenBank Accession Nos. DQ845488- DQ845562 and DQ898223-36 for cyt $b$ gene and DQ845564-DQ845600 and DQ898237-48 for beta-actin gene)

conclusion that Sado and Lagoa de Albufeira are the most diverse populations, contrasting with the low diversity of the "West" (see Table 1). Overall, Sado seams to be the most diverse population. Lagoa de Albufeira comes next, which is surprising because a water body of a few hectares harbours more diversity than all samples from "West", which cover many tens of kilometres of eight different rivers (Table 1).

For the beta-actin gene, only two haplotypes were found: one for each group, "West" (including all the individuals from Lagoa de Albufeira) and Sado. The samples from Sado differ from those of "West" and Lagoa de Albufeira by two fixed mutations, one substitution and one indel of two bases. C. almacai (including individuals both from Arade and Mira basins) presented their own haplotype.

\section{Discussion}

Two divergent groups were distinctly identified within the very small distribution area of $C$. lusitanicum: one from Sado and another from "West" and Lagoa de Albufeira.

As stated above, for the beta-actin gene, the samples from Sado differ from those of "West" and Lagoa de Albufeira by two fixed mutations. This difference is not trivial. For instance, in Squalius pyrenaicus and Squalius carolitertii, two sister species that according with cyt $b$ data diverged about 4-6 MYA (Sanjur et al. 2003) the same sequence is still present in the majority of fish of both species sampled so far (Robalo et al. 2006). For the cyt $b$ gene, the mean divergence between Sado and "West" and between Sado and Lagoa de Albufeira, after correcting for within population variation, was $2.01 \%$ and $1.9 \%$ respectively. Assuming a clock calibration of $1.05 \%$ divergence between lineages per million years (Dowling et al. 2002) we find that the population from Sado diverged from the group "West"/Lagoa de Albufeira about 2 million years ago in the Plio-Pleistocene boundary. Taken together, the available evidence suggests that we may be in the presence of two distinct species, stressing the need of further genetic and morphological investigations. Regardless of the decision on this issue we believe that this paper provides strong evidence that the populations from the Sado must be recognized as an ESU that deserves specific conservation measures. From the groups studied this group showed the highest level of genetic diversity, despite the fact that the fish came from a single location.

The populations of "West" and Lagoa de Albufeira share the same beta-actin haplotype and the corrected $p$ distance between the two groups for cyt $b(0.13 \%)$ 


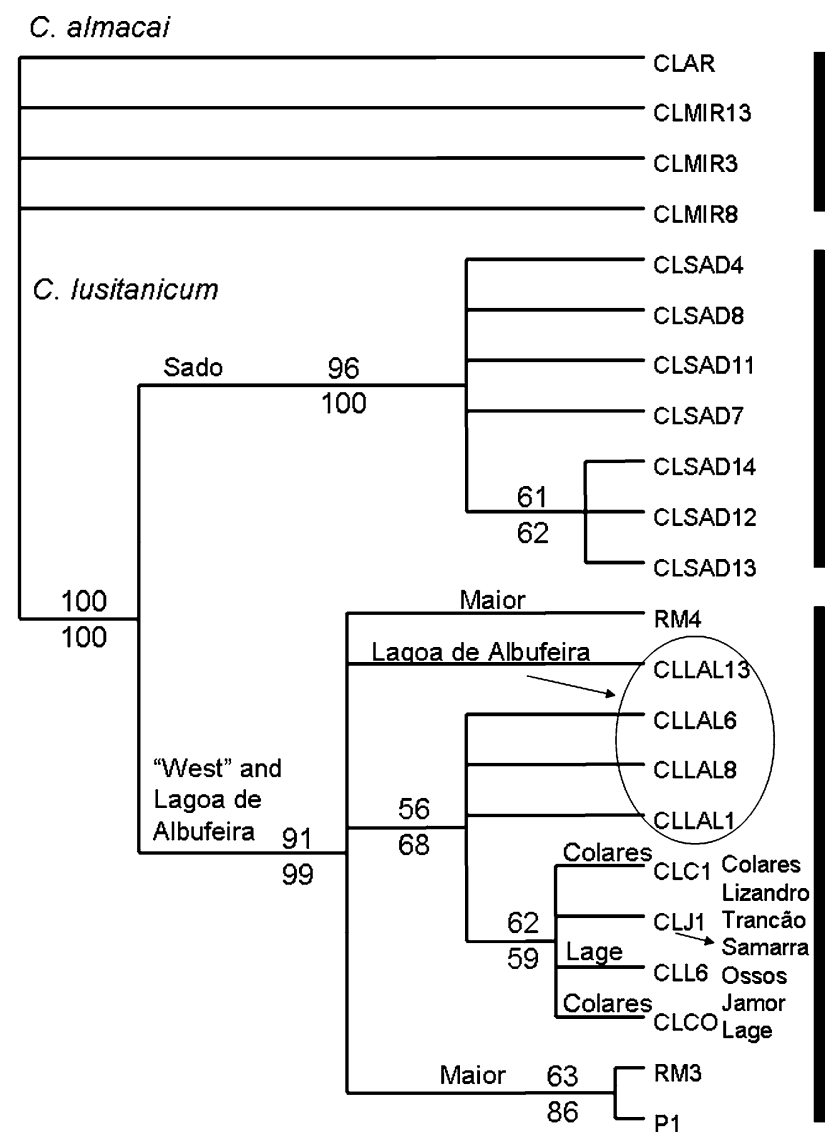

Fig. 2 Tree of cyt $b$ based on MP analysis. Each haplotype was included only once in the tree, regardless of the number of fish that presented it. Numbers above branches represent bootstrap values for MP (1,000 replicates) and numbers below branches represent bootstrap values for NJ (100 replicates). C. almacai haplotypes were used as outgroups. Distribution of haplotypes per drainages is also presented in the terminal branches. Black vertical bars represent the three beta-actin haplotypes. Labels, numbers of fish and distribution for each haplotype: CLSAD14: 5 fish, Sado; CLSAD12: 1 fish, Sado; CLSAD13: 1 fish, Sado; CLSAD4: 4 fish, Sado; CLSAD8: 1 fish, Sado; CLSAD11: 1 fish, Sado; CLSAD7: 1 fish, Sado; CLLAL13: 3 fish, Lagoa de Albufeira; CLLAL6: 1 fish, Lagoa de Albufeira; CLLAL8: 1 fish, Lagoa de Albufeira; CLLAL1: 7 fish, Lagoa de Albufeira; CLC1: 1 fish, Colares; CLJ1: 32 fish, Colares, Lizandro, Trancão, Samarra, Ossos, Jamor and Lage; CLL6: 1 fish, Lage; CLCO: 1 fish, Colares; RM3: 2 fish, Maior; P1: 2 fish, Maior; RM4: 1 fish, Maior; CLAR: 1 fish, Arade; CLMIR13: 16 fish, Arade and Mira; CLMIR3: 5 fish; Mira; CLMIR8: 1 fish, Mira

suggests a divergence time of about 130,000 years. This group includes two distinct ESUs, which are supported by the FST values for cyt $b$. Indeed, not a single haplotype was shared among them. In spite of its minute size the ESU of Lagoa de Albufeira presents a comparatively high level of genetic diversity which, in our view, justifies its preservation.

Within the "West" group, the River Maior shared no haplotypes with the remaining rivers. If the few fish from the River Maior are excluded, the remaining fish from the "West" form a very homogenous group with extremely low genetic diversity dominated by a single haplotype and occupying the tributaries of the estuarine part of the Tagus drainage and a few independent coastal streams located near the Tagus. Indeed, a single haplotype for cyt $b$ (CLJ1) was found in 32 of 39 fish coming from different drainages. The present paper is in apparent contradiction with Mesquita et al. (2001), which suggested the separation of fish from the Tagus from those from Samarra, one of the independent drainages also sampled in our study. It is important to note, however, that Mesquita et al. (2001) only sampled two fish from Tagus and do not state in which part of the basin the fish were collected. In the present study, the Tagus fish that cluster with other drainages of the "West" are those that run to the saline estuary (Trancão, Ossos, Ribeira da Lage e Jamor). Thus, we suggest that while, based on the available data, at least three ESUSs are granted: Sado, Lagoa de Albufeira and "West", further sampling in the Tagus basin may lead to subdivision of this last ESU. The low diversity of this ESU is unlikely to be caused only by repeated bottlenecks as suggested by Mesquita et al. (2001), but also, at least in part, by the likely young age of the populations of the area, as suggested by the sharing of a common haplotype by the great majority of fish of seven different rivers.

Acknowledgments We thank C. Sousa-Santos and T. Bento for all the help in sample collection and fish maintenance, respectively and M. Arruda for the samples from the River Maior. DGRF ("Direcção Geral dos Recursos Florestais") and ICN ("Instituto da Conservação da Natureza") provided all authorizations for field work. We also thank an anonymous referee for all the helpful comments provided. This study was funded by the Pluriannual Program (FCT, UI\&D 331/94, partially FEDER funded).

\section{References}

Cabral MJ, Almeida J, Almeida PR, Dellinger T, Ferrand de Almeida N, Oliveira ME, Palmeirim JM, Queiroz AI, Rogado L, Santos-Reis M (eds) (2005) Livro Vermelho dos Vertebrados de Portugal. Instituto de Conservação da Natureza, Lisboa

Coelho MM, Mesquita N, Collares-Pereira MJ (2005) Chondrostoma almacai, a new cyprinid species from the southwest of Portugal, Iberian Peninsula. Folia Zool 54(1-2):201-212

Dowling TE, Tibbets CA, Minckley WL, Smith GR (2002) Evolutionary relationships of the plagopterins (Teleostei: Cyprinidae) from cytochrome $b$ sequences. Copeia 2002:665-678

Excoffier L, Smouse PE, Quattro JM (1992) Analysis of molecular variance inferred from metric distances among DNA haplotypes: application to human mitochondrial DNA restriction data. Genetics 131:479-491

Mesquita N, Carvalho G, Shaw P, Crespo E, Coelho MM (2001) River basin-related genetic structuring in an endangered fish 
species, Chondrostoma lusitanicum, based on mtDNA sequencing and RFLP analysis. Heredity 86:253-264

Robalo JI, Sousa Santos C, Levy A, Almada VC (2006) Molecular insights on the taxonomic position of the paternal ancestor of the Squalius alburnoides hybridogenetic complex. Mol Phylogenet Evol 39:276-281

Sambrook J, Fritsch EF, Maniatis T (1989) Molecular cloning: a laboratory manual 2nd edn. Cold Spring Harbor Laboratory Press, NY

Sanjur OI, Carmona JA, Doadrio I (2003) Evolutionary and biogeographical patterns within Iberian populations of the genus Squalius inferred from molecular data. Mol Phylogenet Evol 29:20-30
Schneider S, Roessli D, Excoffier L (2000) ARLEQUIN Version 2.000: a software for population genetics analysis. University of Geneva, Geneva

Swofford DL (1998) PAUP *-phylogenetic analysis using parsimony (* and other methods) version 4.0. Sinauer Associates, Sunderland, MA

Waples RS (1991) Pacific salmon, Oncorhynchus spp., and the definition of "species" under the Endangered Species. Act Mar Fish Rev 53(3):11-22

Thompson JD, Gibson TJ, Plewniak F, Jeanmougin F, Higgins DG (1997) The Clustal $X$ windows interface: flexible strategies for multiple sequence alignment aided by quality analysis tools. Nucleic Acids Res 24:4876-4882 